\title{
Current Applications and Future Perspectives of Brain Tumor Imaging
} 뇌종양 영상의 현재와 미래

\author{
Ji Eun Park, MD $\mathbb{D}$, Ho Sung Kim, MD*
}

Department of Radiology and Research Institute of Radiology, University of Ulsan College of Medicine, Asan Medical Center, Seoul, Korea

Anatomical imaging is the basis of the diagnosis and treatment response assessment of brain tumors. Among the existing imaging techniques currently available in clinical practice, diffusion-weighted imaging and perfusion imaging provide additional information. Recently, with the increasing importance of evaluation of the genomic variation and heterogeneity of tumors, clinical application of imaging techniques using radiomics and deep learning is expected. In this review, we will describe recommendations for magnetic resonance imaging protocols focusing on anatomical images that are still important in the clinical application of brain tumor imaging, and the basic principles of diffusion-weighted imaging and perfusion imaging among the advanced imaging techniques, as well as their pathophysiological background and clinical application. Finally, we will review the future perspectives of radiomics and deep learning applications in brain tumor imaging, which have been studied to a great extent due to the development of computer technology.

Index terms Brain Neoplasm; Magnetic Resonance Imaging; Diffusion; Perfusion; Machine Learning

\section{서론}

뇌종양 영상은 최신 영상기법의 테스트베드(testbed)라고 해도 과언이 아니다. 또한 뇌종 양의 이질성(heterogeneity), 난치성 및 수술적 접근의 어려움 때문에 비침습적인 뇌영상의 임상적인 활용 가치가 높아서 최근까지도 다양한 영상기법이 개발되고 있다. 현재까지는 기 관마다 다양한 뇌종양 영상기법으로 촬영하고 있으나 최근 뇌 교종 및 전이성 뇌암에 대한 영상 촬영 가이드라인이 개발되기 시작하면서 다기관 연구 및 임상시험에도 최신 뇌종양 영 상기법이 가능하도록 노력하고 있다. 뇌종양의 2016 세계보건기구(World Health Organization; 이하 WHO) 분류법에 따라 아이소시트레이트 탈수소효소(isocitrate dehydroge- 
nase; 이하 IDH)의 변이 등 유전체 변이가 뇌교종의 진단 분류에 이용되기 시작하여 이를 예측하 는 뇌종양 영상 소견에 대한 연구가 활발하며 본 종설에서도 소개하고자 한다.

최근 뇌종양 영상 가이드라인에서는 해부학적 영상과 더불어 확산 강조 영상(diffusionweighted imaging)과 관류 영상 중 동적 자화 강조 영상(dynamic susceptibility imaging)을 3차 의료기관에서 권유하고 있는데 이는 종양의 미세환경 중 각각 세포 밀도(cellularity)와 혈관 증식(angiogenesis)을 반영한다고 알려져 있기 때문이다. 두 영상기법의 대표적인 임상적인 활용 은 종양과 비종양의 감별, 종양 내 생검 위치 가이드, 주요 뇌 악성 종양의 감별, 유전체 변이 예측, 치료 후 반응 평가가 있으며 현재까지도 많은 연구들이 이루어지고 있다. 이에 본 종설에서는 임상 에서 이용되고 있는 해부학적 영상과 최신 영상기법들의 뇌종양 병태생리와의 연관성에 대해서 살펴보고자 한다.

마지막으로 최근 컴퓨터 비전, 영상처리기술, 인공지능 등의 많은 기술적 진보와 더불어 라디오 믹스(radiomics)와 딥러닝이 영상에서 각광받고 있는데 특히 뇌종양 영상 획득, 처리, 분석, 결과 보고 등에 잠재적인 활용가치를 인정받아 많은 연구가 진행되고 있다. 이는 현재 디지털 사회에서 영상 알고리듬의 고도화, 영상처리 성능의 개선 및 업무 효율도를 증가시킬 수 있어 뇌종양뿐만 아니라 다양한 뇌질환에서 영상의 활용가치가 증가될 것으로 기대되며 이에 대해 본 종설에서 간단 하게 소개하고자 한다.

\section{해부학적 영상 및 자기공명영상 촬영 권고안}

\section{해부학적 영상}

해부학적 영상은 T1-강조영상, T2-강조영상, fluid-attenuated inversion recovery (이하 FLAIR), T2*-경사자장 영상, 조영증강 후 T1-강조영상이 있다. 이는 세부적인 해부학적 특징을 잡 아내고, 조영증강을 함으로써 혈관-뇌 장벽이 손상된 부분을 찾을 수 있다. 하지만 해부학적 영상 은 분명한 한계점이 있는데, 치료 전 뇌교종에서 II/III 등급을 구분하는 것은 어렵다. 실제로 저등 급인 oligodendroglioma는 50\% 정도에서 조영증강을 보이는 반면, 고등급 교종의 $1 / 3$ 정도는 조 영증강을 보이지 않는다(1). 또한 치료 후 뇌종양에서 잔류 종양과 재발을 감별하는 데에도 한계가 있으며, 이를 위해 해부학적 영상 외에 다른 영상기법의 도움이 필요하다(2). 해부학적 영상이 도 움이 되는 경우는 다음과 같다.

\section{원발성 뇌종양의 감별}

조영증강 영상에서 불규칙적인 링 모양의 병변이 보인다면, 드문 다발성 경화증부터 뇌농양, 면 역이 저하된 환자의 악성 림프종, 교모세포종(glioblastoma) 등의 감별 질환이 가능하다. 이중 교 모세포종으로 대표되는 원발성 뇌종양은 주변 뇌조직을 침습하는 특징을 보이므로, FLAIR를 이 용하여 조영증강되는 병변 주변의 ‘조영증강되지 않는 종양 부위'를 발견한다면, 원발성 뇌종양과 다른 병변을 구분할 수 있다(Fig. 1). 
Fig. 1. A non-enhancing infiltrative tumor portion in the peri-enhancing lesion on T2-weighted images helps to distinguish a primary from a secondary central nervous system tumor.

A. A portion with $\mathrm{T} 2$ iso-to-low signal intensity extending to the cortex is shown in brain glioma (arrows indicates nonenhancing tumor portion).

B. A finger-like projection edema surrounding the solid tumor portion is shown in a metastatic brain tumor (arrow indicates edema without cortex extension).
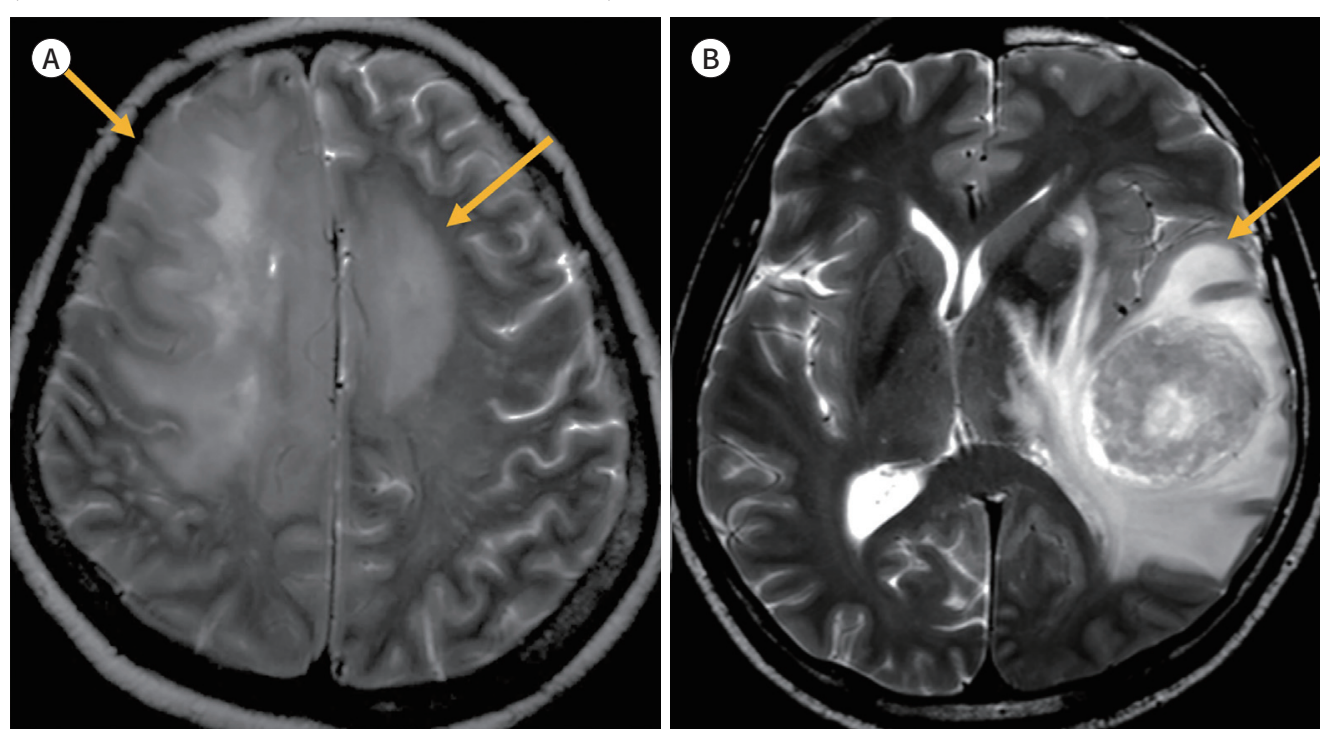

\section{유전체 변이 진단}

업데이트된 2016 세계보건기구(WHO) 분류법에 따르면 모든 뇌교종은 IDH 변이와 $1 p / 19 q$ 소 실 유무에 따라 분류될 수 있다. 핍지교종(oligodendroglioma)은 IDH 변이와 $1 \mathrm{p} / 19 \mathrm{q}$ 소실이 모 두 발견되며, 저등급 성상세포종(diffuse astrocytoma)은 IDH 변이만 관찰되고 $1 \mathrm{p} / 19 \mathrm{q}$ 소실은 없 다. 성상세포종 중에서 일부 아형은 T2/FLAIR 불일치(mismatch)를 보이게 되는데, 이 징후가 보 인다면 $\mathrm{IDH}$ 변이가 동반된 성상세포종의 가능성이 높다는 연구 결과들이 있어 매우 흥미롭다. 문 헌에 따르면 이는 두 가지의 특징을 보여야 한다(3). 첫 번째로 T2-강조영상에서 종양의 전체 또는 많은 부분이 균등한 고신호강도를 보이며, 두 번째로 T2-강조영상에서 보였던 고신호강도 부위가 FLAIR 영상에서 종양 테두리를 제외한 나머지 부분은 저신호강도로 바뀌는 특징이 있다. 이 소견 은 민감도는 22 46\%로 다양하나 매우 높은 특이도를 보이며, 양성 예측도는 거의 $100 \%$ 이다. 반 대로 IDH 변이가 없는(IDH-wild type) 성상세포종에서는 T2-FLAIR 불일치 소견이 관찰되지 않 는다(Fig. 2) $(4,5)$.

\section{조영증강 병변의 측정}

해부학적 영상의 가장 중요한 역할은 원발성 뇌종양, 특히 교모세포종 환자에서 치료 후 조영증 강 병변의 크기를 객관적으로 측정하는 일이다. 뇌종양 치료 반응 평가의 현재 표준은 Response Assessment of Neuro-Oncology (이하 RANO) criteria를 따르게 되는데, 이는 조영증강 병변에 서 가장 긴 장축과 이에 수직 되는 단축의 길이를 측정한 후 이를 곱하는 이차원 측정법을 이용하 고 있다(6). RANO criteria 기반의 이차원 측정법은 조영증강 병변이 불규칙한 경우 사람마다 측 
Fig. 2. T2/FLAIR mismatch sign.

A. A tumor in the left frontal lobe and insular cortex displays complete or near-complete and almost homogeneous hyperintense signal on T2-weighted images.

B. On T2-weighted FLAIR sequence, the tumor displays relatively hypointense signal, except for a hyperintense peripheral rim. The patient was diagnosed with isocitrate dehydrogenase mutation, $1 \mathrm{p} / 19 \mathrm{q}$ co-deleted subtype of diffuse astrocytoma on pathology.

FLAIR = fluid attenuated inversion recovery
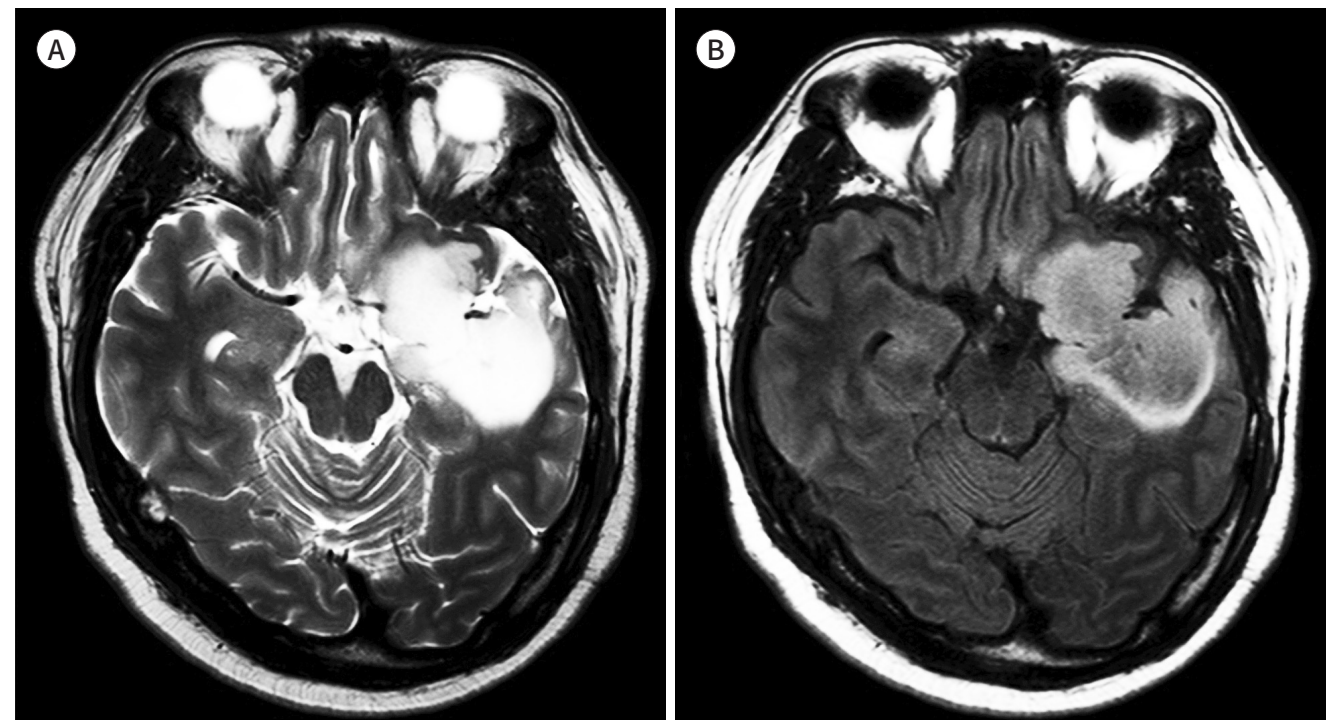

정값이 상이 할 수 있어 측정의 재현성(reproducibility)이 떨어지는 단점이 있다. 이를 극복하고 자 최근에는 삼차원적인 용적 측정법이 소개되고 있다. 하지만 이는 전용 소프트웨어의 도움이 필 요하다. 최근에는 딥러닝을 이용한 자동적인 종양 분할 및 용적 측정이 소개되어 측정시간을 줄이 고 재현성을 높일 수 있어 많은 기대가 되고 있다. 딥러닝의 응용에 대해서는 글 후반부에 소개하 도록 하겠다. 원발성 뇌종양 특히 교모세포종의 치료 후 반응 평가에서 특이할 점은 종양의 거짓 진행(pseudoprogression)인데 이는 실제 종양은 커지지 않았지만 방사선치료와 항암제의 효과 로 인해 혈액-뇌장벽(blood-brain-barrier; $\mathrm{BBB})$ 이 파괴되고 염증반응 등으로 인하여 조영증강 병변이 커지는 경우로 해부학적 영상만으로는 판단하기가 어려운 경우가 많아 환자의 치료 계획 에 어려움이 있다. 최근에서 확산 강조 영상과 관류 영상 등이 종양의 거짓진행의 진단에 도움이 된다는 연구 결과들이 많다. 이에 대해서는 다음 챕터에서 상세히 다루도록 하겠다.

\section{자기공명영상 촬영 권고안}

\section{원발성 뇌종양: 뇌교종}

2015년도에 다기관 임상시험을 위한 뇌종양 영상 촬영 권고안이 발간되었다(7). 이는 악성 원발 성 뇌종양의 $45 \%$ 를 차지하며(8), 질환의 양상이 복잡하고 난치성인 교모세포종을 위해 최적화되 었다. 교모세포종의 치료는 아직 테모졸로마이드 이후에 생존을 의미 있게 증가시키는 약제가 개 발되지 않았다. 따라서 많은 임상시험을 통한 새로운 치료약제의 개발이 시급한 분야로 꼽힌다. 권고안의 목적은 다기관 임상시험을 위해 영상 촬영기법의 표준화, 임상시험 치료약제의 치료 반 
Table 1. Summary of the Minimum and Recommended Protocols for Clinical Trial Imaging for Brain Glioma and Metastasis

\begin{tabular}{|c|c|c|}
\hline & Minimum Protocol & Recommended Protocol \\
\hline \multicolumn{3}{|l|}{ Glioma } \\
\hline Tesla & $1.5 \mathrm{~T}$ or $3.0 \mathrm{~T}$ & $3.0 \mathrm{~T}$ \\
\hline \multirow[t]{4}{*}{ Pre-contrast } & 3D T1WI, IR-GRE*,$\leq 1.5 \mathrm{~mm}$ & 3D T1WI, IR-GRE*, $1 \mathrm{~mm}$ \\
\hline & 2D FLAIR imaging, TSE or FSE, $\leq 4 \mathrm{~mm}$ & 2D FLAIR imaging, TSE or FSE, 3 mm \\
\hline & 2D DWI, single-shot EPI, $\leq 4 \mathrm{~mm}$ & 2D DWI, EPI, $3 \mathrm{~mm}$ \\
\hline & 2D T2WI, TSE or FSE, $\leq 4$ mm (either pre-or post-contrast) & 2D T2WI, TSE or FSE, $3 \mathrm{~mm}$ (either pre-or post-contrast) \\
\hline Post-contrast & 3D T1WI, IR-GRE*,$\leq 1.5 \mathrm{~mm}$ & 3D T1WI, IR-GRE, $1 \mathrm{~mm}$ \\
\hline Summary of differences & \multicolumn{2}{|c|}{ Recommended protocol is obtained with $3.0 \mathrm{~T}$, with thinner section, and with multi-shot EPI acquisition of DWI } \\
\hline \multicolumn{3}{|l|}{ Brain metastasis } \\
\hline Tesla & $1.5 \mathrm{~T}$ & $3.0 \mathrm{~T}$ \\
\hline \multirow[t]{4}{*}{ Pre-contrast } & \multirow[t]{4}{*}{ Same as the minimum protocol of glioma } & 3D T1WI, $\mathrm{TSE}^{\dagger}, 1 \mathrm{~mm}$ \\
\hline & & 2D FLAIR imaging, TSE or FSE, 3 mm \\
\hline & & 2D DWI, Single-shot EPI, 3 mm \\
\hline & & 2D T2WI, TSE or FSE, $3 \mathrm{~mm}$ (either pre-or post-contrast) \\
\hline \multirow[t]{2}{*}{ Post-contrast } & Same as the minimum protocol of glioma & 3D T1WI, $\mathrm{TSE}^{\dagger}, 1 \mathrm{~mm}$ \\
\hline & Except 2D T1WI, TSE or SE, $\leq 4 \mathrm{~mm}$ & $\begin{array}{l}\text { Dynamic susceptibility contrast imaging, gradient-EPI, } \\
3-5 \mathrm{~mm} \text { as needed to cover tumor }\end{array}$ \\
\hline Summary of differences & \multicolumn{2}{|c|}{$\begin{array}{l}\text { Compared with glioma imaging, metastasis imaging has additional post-contrast T1-weighted SE imaging } \\
\text { Ideal protocol for metastasis recommends TSE for all anatomic imaging }\end{array}$} \\
\hline
\end{tabular}

*For detailed information, please refer to reference (7) and reference (9). According to references, "IR-GRE is equivalent to magnetization prepared rapid gradient-echo (MPRAGE; Siemens \& Hitachi), inversion recovery spoiled gradient-echo (IR-SPGR or Fast SPGR with inversion activated or BRAVO; GE), or 3D turbo field echo (TFE; Philips), or 3D fast field echo (3D Fast FE; Toshiba)."

${ }^{\dagger}$ For 3D T1-weighted TSE, acceptable sequences are VISTA (Philips), SPACE (Siemens), CUBE (GE), 3D MOX (Canon) or iso FSE (Hitachi).

$\mathrm{D}=$ dimensional, $\mathrm{DWI}=$ diffusion weighted imaging, $\mathrm{EPI}=$ echo planar imaging, FLAIR = fluid attenuated inversion recovery, FSE $=$ fast spin echo, IR-GRE = inversion-recovery gradient-recalled echo sequence, SE = spin echo, T = Tesla, T1WI = T1-weighted imaging, T2WI = T2-weighted imaging, TSE = turbo spin echo

응 평가를 위한 정량적인 영상 지표의 검증, 그리고 이를 통해 현재의 표준 뇌종양 치료 반응 평가 지표인 RANO criteria의 한계를 보완하기 위함이었다. 여기에는 일반 중소병원을 위한 최소 프로 토콜(minimum protocol)과 진료뿐만 아니라 연구가 활성화되어 있는 3차 병원을 위한 권장 프 로토콜(recommended protocol)로 나누어져 있으며, Table 1에 정리되어 있다. 최소 프로토콜은 $1.5 \mathrm{Tesla}$ (이하 T)나 3.0 T 모두에서 촬영 가능하며 포함되는 영상 시퀀스들은 조영증강 전후 등방 성(isotropic) 3 차원 $\mathrm{T} 1$ 강조영상, 조영증강 전 2차원 $\mathrm{T} 2$ 강조영상, 조영증강 전 2차원 FLAIR 영상, 조영증강 전 2차원 확산 강조 영상이다. 권장 프로토콜은 $3.0 \mathrm{~T}$ 에서만 촬영 가능하고 조영증강 전 후의 역전회복(inversion recovery)이 포함된 등방성 3차원 $\mathrm{T} 1$ 강조 경사자장 영상, 조영증강 전 2차원 FLAIR 터보스핀에코 영상, 조영증강 전 2차원 확산 강조 영상, 조영증강 전 2차원 T2 강조 영상이 포함된다. 최소 프로토콜과 비교해서 권장 프로토콜에서는 $3.0 \mathrm{~T}$ 에서만 영상을 촬영한다 는 점, 더 얇은 slice thickness로 촬영한다는 점, 확산 강조 영상이 single-shot echo planar imaging이 아닌 multi-shot을 이용한다는 차이점이 있다. 


\section{전이성 뇌종양}

2020년에 다기관 임상시험을 위한 전이성 뇌종양 영상 촬영 권고안이 발간되었다(9). 전이성 뇌 종양은 원발성 뇌종양에 비해 훨씬 높은 빈도로 발생한다(10). 뇌교종을 중심으로 한 원발성 뇌종 양의 치료 반응 평가와 마찬가지로 전이성 뇌종양을 위한 표준 치료 반응 평가지표는 RANOBrain Metastasis (RANO-BM)이다(11). 이는 영상 소견, 스테로이드 용량과 환자의 임상 증상을 종합적으로 평가하여 전이성 뇌종양의 치료 반응을 객관적으로 평가하기 위한 것으로, 다기관 임 상시험에서 공통적으로 사용하기 위해서는 영상 프로토콜 표준화가 중요하다. 치료 후 전이성 뇌 종양의 영상평가의 중요한 두 가지 목적은 첫째, 작은 전이성 뇌종양을 놓치지 않고 잘 찾는 것이 며 이를 위해 고해상도 영상기법이 필요하며, 둘째, 정위 방사선 치료나 면역 치료 후에 전이성 뇌 종양의 악화와 치료 효과를 정확하게 진단할 수 있는 최신 영상기법이며 주로 관류 영상을 권고하 고 있다. 원발성 뇌종양의 영상 프로토콜과 유사하게 최소(minimum) 프로토콜과 이상적인(Ideal) 'Recommended' 프로토콜로 나누어져 있으며 Table 1에 정리되어 있다. 최소 프로토콜은 1.5 $\mathrm{T}$ 에서만 촬영 가능하며 조영증강 전후의 등방성 3차원 $\mathrm{T} 1$ 강조영상 $(1.5 \mathrm{~mm}$ 크기 이하), 조영증강 후 2차원 스핀에코나 터보스핀에코 $\mathrm{T} 1$ 강조영상, 조영증강 전 2차원 $\mathrm{T} 2$ 강조영상, 조영증강 전 2차 원 FLAIR 영상, 조영증강 전 2차원 확산 강조 영상이 포함되어 있다. 전이성 뇌종양을 위한 이상 적인 프로토콜은 $3.0 \mathrm{~T}$ 에서만 촬영 가능하고 해부학적 영상은 모두 터보스핀에코이며 포함되는 영상 시퀀스는 조영증강 전후 3차원 등방성 $\mathrm{T} 1$ 강조 터보스핀에코 영상( $1 \mathrm{~mm}$ 두께), 조영증강 후 2 차원 터보스핀에코 $\mathrm{T} 1$ 강조영상, 조영증강 전 2차원 $\mathrm{T} 2$ 강조영상, 조영증강 전 2차원 FLAIR 영 상, 조영증강 전 2차원 확산 강조 영상, 동적 자화강조 관류 영상이다.

간략히 요약하면, 조영증강 $\mathrm{T} 1$ 강조영상은 모든 프로토콜에 공통되는 핵심 영상으로 최적 시퀀 스가 무엇인가에 대해서는 현재까지 논란의 여지가 있다. $3.0 \mathrm{~T}$ 가 $1.5 \mathrm{~T}$ 보다 우수한 것에 대해서는 이견이 없다. 자화준비 3차원 경사자장에코 계열의 시퀀스가 신호대잡음비가 높고 해부학적 구조 물을 고해상도로 관찰하는 데 유용하여 많은 뇌종양 센터에서 사용하고 있다. 하지만 스핀에코 시 퀀스 계열의 $\mathrm{T} 1$ 강조영상보다 조영증강 후 종양의 대조도가 떨어지는 단점이 있고, 특히 백질의 신호가 높아서 특히 백질 내 조영증강되는 전이성 종양의 대조도가 떨어지는 단점이 있다. 또 다 른 3차원 경사자장에코 계열 시퀀스의 단점으로는 두개뼈의 전이성 종양이 불분명할 수 있다는 점이다. 터보스핀에코 계열의 조영증강 $\mathrm{T} 1$ 강조영상으로는 회사마다 CUBE (GE), SPACE (Siemens), VISTA (Philips) 등의 이름으로 불리며 이는 자화전도(magnetization transfer) 효과가 있 어 백질이 낮은 신호를 보이고 따라서 조영증강 병변의 대조도가 높아진다. 또한 혈류의 신호 억 제 효과도 있어서, 전이성 뇌종양의 이상적인 프로토콜에 포함된다. 한편 전이성 뇌종양을 위한 이상적인 프로토콜에는 관류 영상에 대한 필요성이 언급되어 있으며, 이는 감마나이프와 같은 정 위 방사선 치료 후 조영증강되는 병변에 대해 종양 재발과 방사선 괴사와 같은 치료 효과를 감별 하기 위해 선택적으로 추가할 수 있다고 기술되어 있다. 관류 영상의 진단적 가치는 다음 단락에 서 설명하고자 한다. 
Fig. 3. A 61-year-old male with recurrent glioblastoma who underwent anti-angiogenic therapy.

The internal very low ADC value (blue arrows) represents coagulation necrosis and the peripheral low ADC value (green circles) represents increased tumor cellularity, indicating that the low ADC represents not only high cellularity, but also coagulation necrosis from the treatment. The left two images are contrast-enhanced T1-weighted image and fluid attenuated inversion recovery image, showing infiltrative tumor portion. The right two images are diffusion-weighted image (upper) and ADC images (lower).

$\mathrm{ADC}=$ apparent diffusion coefficient

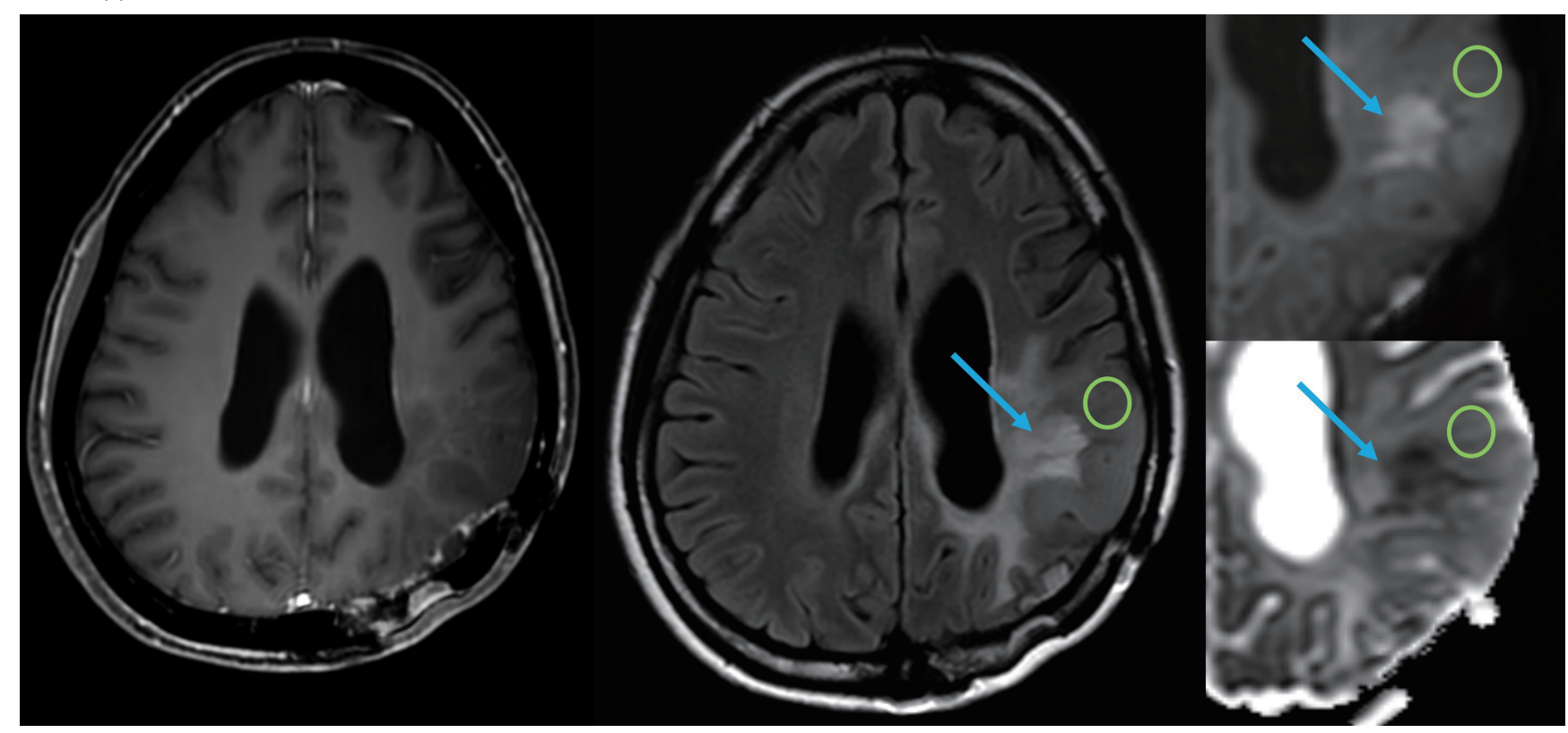

확산 강조 영상 및 관류 영상의 특징 및 임상 응용

\section{확산 강조 영상(Diffusion-Weighted Imaging)}

\section{기본원리 및 병태생리학적 기전}

확산 강조 영상은 물 분자의 확산 운동을 영상화한 것으로 미세환경인 복셀(voxel) 내의 물 분자 의 움직임을 반영한다. 물 분자는 세포 외, 세포 내와 혈관 사이 공간에 분포되어 있으며 이들 해부 학적 공간의 분포에 따라 확산 강조 신호강도에 영향을 미친다. 임상에서 가장 많이 이용하는 것 은 두 개의 $\mathrm{b}$-value $\left(\mathrm{b}=0\right.$ 과 $\left.\mathrm{b}=1000 \mathrm{sec} / \mathrm{mm}^{2}\right)$ 를 촬영하여 현성확산계수(apparent diffusion coefficient; 이하 $\mathrm{ADC}$ )를 계산한 것이다. $\mathrm{ADC}$ 는 주로 세포 외 및 혈관 외(extracellular and extravascular)에 존재하는 물 분자의 움직임을 반영하며 세포 내에 있는 가장 느린 물 분자의 움직 임을 반영하지는 못한다. $\mathrm{ADC}$ 는 세포 밀도와 역상관관계가 있다는 것은 잘 알려져 있는데, 이는 종양세포의 밀도가 높을수록 세포 외 공간이 감소하여 상대적으로 물 분자의 움직임이 감소하게 되며 결론적으로 $\mathrm{ADC}$ 가 감소하게 된다 $(12,13)$. 이전 연구에서 $\mathrm{ADC}$ 값과 세포 밀도의 상관관계 는 약 $r=-0.66$ (95\% 신뢰구간: - $0.85,-0.47)$ 로 알려져 있다(14).

$\mathrm{ADC}$ 를 이용한 확산 강조 신호의 해석에 주의할 점은 낮은 $\mathrm{ADC}$ 는 주로 높은 세포 밀도를 반영 하나, 종양 내에서 허혈 및 응고 괴사에 의한 소견도 낮은 $\mathrm{ADC}$ 값을 보이는 점에 주목해야 한다 (Fig. 3). 이는 종양 내의 이질성(heterogeneity)이 심한 고등급의 악성 종양에서 더 많이 보이는 
소견이다. 따라서 평균 $\mathrm{ADC}$ 값을 가지고 모든 종양 부위를 설명하는 것은 어렵다. 하지만 최근 아 미노산 대사를 이용한 양성자 촬영과 $\mathrm{ADC}$ 값을 비교한 연구에 따르면 높은 아미노산 활성도와 낮 은 $\mathrm{ADC}$ 사이의 연관성은 별로 없었으며 $(15,16)$, 이는 $\mathrm{ADC}$ 감소가 세포 밀도 증가뿐 아니라 종양 에 의한 혈관압박(compression) 및 허혈에 의한 비중도 있음을 의미한다.

악성 뇌종양은 세포 밀도와 혈관분포(vascularity)가 양성 뇌종양보다 훨씬 높고 복잡하다. 이때 높은 세포 밀도는 $\mathrm{ADC}$ 를 낮추지만, 높은 혈관분포는 $\mathrm{ADC}$ 를 높일 수 있는데, 이는 확산 강조 영상 신호가 높아지기 때문이다. 따라서 $\mathrm{ADC}$ 는 과혈관성 종양에서 평가절하(underestimation) 될 수 있다는 사실을 기억해야 한다.

이외에 서로 다른 물 분자 확산의 원리를 이용한 diffusion kurtosis, intravoxel incoherent motion이 존재하나 이들은 이전 영상의학과 의사를 위한 새로운 영상기법 리뷰(17)에서 다루어 졌으며, 본 종설에서는 다루지 않겠다.

\section{동적 자화강조 관류 영상(Dynamic Susceptibility Contrast Perfusion Imaging)}

\section{기본원리 및 병태생리학적 기전}

동적 자화강조 관류 영상은 가돌리늄 조영제를 정맥 내에 주입한 후 조영제가 혈관을 따라 처음 으로 뇌조직을 순환(first-pass) 하게 되면, 혈관 내의 높은 조영제 농도에 의해 자장의 불균일성이 유도되어 혈관 주위 뇌조직의 신호강도가 감소되는( $\mathrm{T} 2$ 혹은 $\mathrm{T} 2 *$ 이완 시간 단축) 원리를 이용한 다. 주입된 조영제는 혈관 내와 혈관 외-세포 외(extravascular-extracellular space; EES) 공간에 만 영향을 준다고 가정한다. 이러한 MR 영상신호 변화를 일정 수식을 사용하여 변환하면 단위 조 직내 조영제의 시간-농도곡선에 비례하는 $\triangle \mathrm{R} 2$ 곡선을 만들 수 있다. 이 $\triangle \mathrm{R} 2$ 곡선을 이용하여 영 상처리 과정을 거치면 관류 영상을 구성하게 된다.

뇌종양에서 얻는 대표적인 파라미터는 혈류 용적(cerebral blood volume; 이하 CBV)이며 뇌종 양에서 반대편의 정상적으로 보이는 뇌백질과 비교한 relative $\mathrm{CBV}$ (이하 rCBV)가 가장 많이 사용 되고 있으며(18), 이는 종양 내부에 미세혈관 면적(microvessel area)을 반영한다고 알려져 있다. 특히 뇌종양을 신생혈관 생성(neoangiogenesis)을 반영하는 영상 지표 중 미세혈관 면적은 미세 혈관 수와 직경을 모두 반영한다. 미세혈관 면적은 종양 신생혈관에 대한 병리학적 지표로 많이 사용하는 미세혈관 밀도(microvessel density)보다 종양의 신생혈관 생성을 보다 정밀하게 반영 하는 것으로 알려져 있다. 특히 원발성 뇌종양의 대표격인 교모세포종에 보이는 특징적인 사구체 모양(glomeruloid) 혈관은 대표적인 종양 신생혈관의 형태인데 이는 높은 미세혈관 면적을 가진 다. 또한 이러한 형태의 신생혈관이 많이 관찰될수록 환자들의 생존율이 떨어진다는 연구 결과도 있다(Fig. 4) (19).

\section{임상응용}

확산 강조 영상에서의 $\mathrm{ADC}$ 와 관류 영상에서의 $\mathrm{rCBV}$ 는 다양한 임상응용을 가지며 크게 종양과 종양 유사 병변의 감별, 원발성 뇌종양의 감별진단 및 등급 결정, 종양 환자의 예후 예측, 특히 치 
Fig. 4. A 40-year-old patient exhibiting high microvessel density and an uneven large vessel pattern on the vessel size index on vessel architectural imaging (lower right side). The patient shows infitrative nonenhancing tumor on fluid-attenuated inversion recovery (left upper) and contrast-enhanced T1-weighted image (right upper) and was diagnosed with molecular glioblastoma (isocitrate dehydrogenase-wild type lowgrade astrocytoma with epithelial growth factor receptor amplification) on pathology that progressed 50 days later.

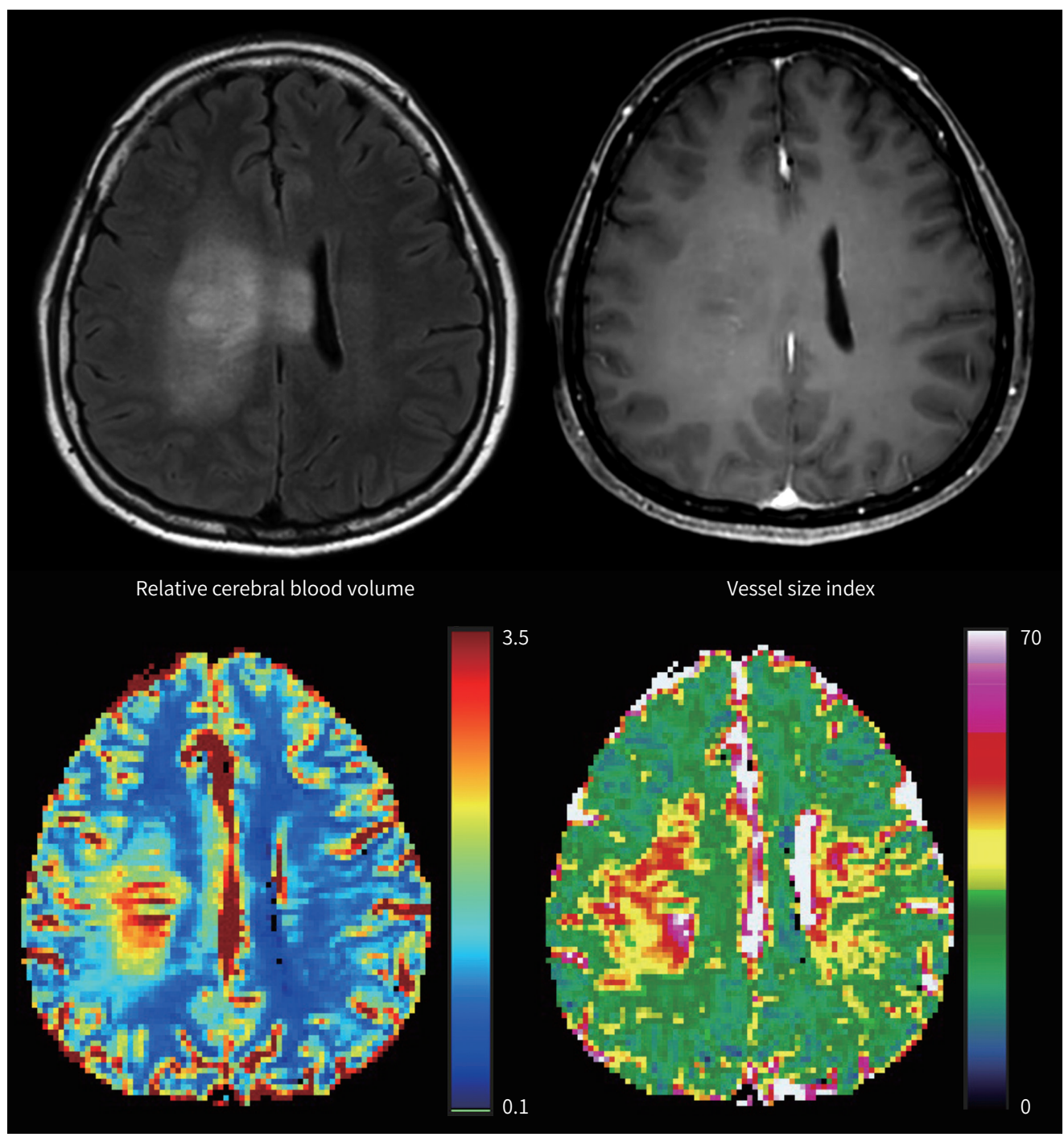

료 후 뇌종양에서 관찰되는 특이 소견인 조영증강되는 병변의 거짓진행(pseudoprogression) 또 는 방사선 괴사와 종양 재발을 감별하는데 유용하며 최근에는 항혈관제(anti-angiogenic drug) 및 새로운 면역치료의 치료 반응 평가를 위한 연구에 많이 이용되고 있다.

\section{종양과 종양 유사 병변의 감별}

중추신경계의 염증성 탈수초 질환이 단일 병변으로 나타날 경우에는 종양 혹은 뇌졸중으로 오 인되어 수술, 방사선치료 혹은 항혈전치료가 행해지는 경우가 종종 있으며, 이로 인해 증상이 진 행하거나 치료로 인한 부작용으로 장애가 남을 수 있다. 따라서 조기에 탈수초 질환에 대한 진단 과 치료가 필요하다. $\mathrm{rCBV}$ 는 종양에서보다 탈수초 질환이나 염증성 질환에서 낮은 것으로 알려 
져 있으며, 염증성 질환을 진단하는데 $95 \%$ 의 정확도를 갖는다고 보고되어 있다(20). 그러나 염증 성 질환에서 결핵이나(21) 종양 유사 탈수초성 질환(tumefactive demyelinating lesion)은 가끔 종양과 비슷한 정도의 높은 $\mathrm{rCBV}$ 를 보일 수 있어 감별진단에 주의를 요한다(22).

\section{원발성 뇌종양의 감별진단(교모세포종과 림프종의 감별)}

원발성 중추신경계 림프종(primary central nervous system lymphoma; 이하 PCNSL)은 다 른 장기로부터 뇌로 전이된 경우가 아닌 뇌와 척수 및 이를 둘러싸고 있는 뇌막에 일차적으로 비 호지킨성 림프종이 발병된 경우이며, 대부분 균질한 조영증강을 나타내서 해부학적 영상만으로도 감별이 가능한 경우가 많다. 그러나 면역이 저하된 환자에서 내부 괴사를 보일 때 교모세포종 및 전이성 뇌종양과 해부학적 영상에서 유사한 소견을 보여 관류 영상이 감별에 도움이 된다. PCNSL은 종양이 성장하기 위해 신생혈관을 생성하기보다는 기존의 혈관 주변으로 세포들이 밀 집되어 종양세포들이 증식하는 형태로 신생 혈관을 직접 왕성하게 생성하는 교모세포종과 비교 해서 낮은 $\mathrm{rCBV}$ 를 보인다(23). 최근 메타 분석에서 이 두 질환을 구분하는데 가장 중요한 단일 영 상으로는 rCBV가 꼽혔으며(24), 여러 영상기법을 조합하였을 때 $\mathrm{ADC}$ 와 고해상도 자화강조 영상 (susceptibility weighted imaging)의 조합하면 민감도, 특이도를 각각 $96 \%$ 와 95\%까지 높일 수 있다고 알려져 있다(25).

\section{방사선, 항암제 치료 후 거짓진행, 방사선 괴사 및 종양 재발의 감별}

현재 교모세포종에서 방사선, 항암제 치료 후 치료 반응 평가 기준은 2010년에 제안한 RANO criteria이다. RANO criteria는 이전 MacDonald criteria를 개편한 것으로 기준 영상이 CT에서 MRI로 바뀌었으며, 항혈관제제에 대한 치료 반응 평가를 위해 조영증강 T1 강조영상 외에 FLAIR 영상에 대한 기준이 추가되었다. 또한 방사선 및 테모졸로마이드(temozolomide) 항암제 치료 후 일시적으로 관찰될 수 있는 거짓진행(pseudoprogression)의 평가에 대한 기준을 제시하였다. 거 짓진행은 교모세포종 치료 후 약 20 30\% 정도 발생하는 것으로 알려져 있으며, 이전 연구들에서 좋은 예후와 연관이 있다고 알려져 있다 $(6,26)$. 하지만 RANO criteria 만으로 거짓진행 또는 치료 과정 중 후기에 발생할 수 있는 방사선 괴사를 종양 재발과 정확히 구분하기는 힘들며 확산 강조 영상과 관류 영상이 감별진단에 일부 도움이 될 수가 있다. 교세포종에서 거짓진행은 종양이 스스 로의 DNA를 수리하는 $\mathrm{O}^{6}$-methylguanine-DNA methyltransferase (이하 MGMT) promoter의 메틸화(methylation)에 영향을 받는 것으로 알려져 있으며 MGMT 메틸화가 된 군이 거짓진행을 잘하고 생존율이 높다고 알려져 있다(27). 보통 거짓진행은 생존(viable) 종양 부위와 치료 효과에 의한 비생존(nonviable) 종양 부위가 혼재되어 있는 것으로 알려져 있고, 방사선, 항암제 치료 후 12 주 이내에 흔히 발생하여 추적검사 중에 방사선 괴사보다는 빨리 관찰된다. 한편 거짓진행의 발 생 자체는 높은 치료 효과를 반영하는 것으로 알려져 있어 좋은 예후를 시사한다고 할 수 있다(27).

뇌종양의 항암제 및 방사선 치료 후에는 세포가 괴사되므로 세포 밀도가 줄어들고, 확산 신호가 높아지게 된다. 이때 b value를 높여서 강한 확산 강조 영상을 얻게 되면 물 분자의 움직임이 더욱 강조되어 비교적 순수한 세포 밀도를 반영하는 $\mathrm{ADC}$ 를 얻을 수 있다(28). 한 연구에서 강한 확산 
강조(high b-value) 영상을 이용하여 치료 후 교모세포종의 거짓진행과 치료 반응 효과를 평가했 을 때 b-value 3000 의 강한 확산 강조 영상이 b-value 1000 의 일반 확산 강조 영상보다 종양 재발 과 거짓진행의 감별 정확도를 유의하게 높일 수 있었다(29).

관류 영상을 이용하여 종양 재발과 거짓진행의 감별은 많은 연구에서 이루어져 왔다. 방사선, 테모졸로마이드 항암제 치료 한 달 후에 거짓진행에서는 $\mathrm{rCBV}$ 가 $41 \%$ 감소하는 반면 종양 재발에 서는 $12 \%$ 가 증가하였다는 연구가 있으며(30), 주로 거짓진행은 낮은 $\mathrm{rCBV}$, 종양 재발은 높은 $\mathrm{rCBV}$ 를 나타낸다. 연구마다 다양한 cut-off가 제시되어 왔는데, 평균값으로 거짓진행은 rCBV 1.7 $\mathrm{mL} / 100 \mathrm{~g}$ 미만, 종양 재발은 rCBV $2.0 \mathrm{~mL} / 100 \mathrm{~g}$ 이상이라고 보고하였다. 최대 rCBV 값(maximum rCBV)을 이용했을 때 cut-off 2.6을 제시한 연구도 있다(31). 근본적으로 생존(viable) 종양 부위와 치료에 반응한 비생존(nonviable) 종양 부위가 혼재되어 있어 관심영역에 대한 평균적인 $\mathrm{rCBV}$ 분석은 한계가 있다. 최근 메타 연구에서 $\mathrm{rCBV}$ 는 민감도 $88 \%$ 및 특이도 $77 \%$ 로 감별력을 보였다(32). 이를 극복하기 위하여 종양의 이질성을 반영하는 근본적인 방법이 필요한데, 단순히 관심영역 내 영상 복셀들의 값의 분포를 표현한 히스토그램 분석이 많이 이용되어져 왔다. 최근에 는 영상처리기술의 발전으로 복셀들의 단순 분포뿐만 아니라 공간적인, 시간적인 이질성을 객관 적, 정량적으로 표현해 줄 수 있는 클러스터링 기법, parametric response map 등이 연구되고 있 다 $(33,34)$. 이는 복셀 단위에서 cut-off를 정해서 작은 신호의 변화도 감지할 수 있으며, 이를 통하 여 전체 평균값이나 전체 최댓값이 변하기 전에 종양의 초기 치료 반응을 효율적으로 예측할 수 있는 가능성이 있다(Fig. 5) (2).

\section{항혈관제(Aanti-Angiogenic Drug) 치료 후 반응 평가}

재발성 교모세포종 환자에서 혈관내피 증식인자(vascular endothelial growth factor)를 억제 하는 항혈관제인 bevacizumab을 사용하게 되는데, 이는 종양의 재발을 늦추는데 도움이 되지만, 환자의 생존 기간(overall survival)을 늘리는 데는 큰 영향을 주지 않는 것으로 알려져 있다(3537). 영상에서 항혈관제는 내피세포 투과성을 감소시켜 조영증강과 뇌실질의 부종을 감소시키기 때문에 종양세포의 치료 반응을 평가함에 있어서 영상 소견의 해석에 주의를 요한다. 따라서 항혈 관제 치료 후에는 조영증강 영상에서 조영증강 부위의 크기가 작아지더라도 종양세포가 줄어들 었다고 쉽게 판단해서는 안 되며 FLAIR 영상에서 조영증강되지 않는 병변 부위의 크기 변화를 반 드시 평가해야 한다. 만일 조영증강 병변은 작아졌지만 FLAIR 영상에서 조영증강되지 않는 병변 부위가 계속 남아있거나 오히려 증가했다면 이를 거짓반응(pseudoresponse)이라고 한다. 따라 서 테모졸로마이드 치료 후에 종양의 거짓진행(pseudoprogression)을 고려해야 하듯이 항혈관 제 치료 후에는 종양의 거짓반응(pseudoresponse)을 반드시 고려해야 한다.

항혈관제 치료 전후 종양의 치료 반응 예측과 평가에서 확산 강조 영상과 관류 영상이 추가적인 정보를 제공한다는 연구 결과들이 있었다. 확산 강조 영상에서 종양 부위는 높은 세포 밀도로 낮 은 $\mathrm{ADC}$ 값을 보이고, 혈관성 부종 부위는 낮은 세포 밀도로 높은 $\mathrm{ADC}$ 값을 보이는 점을 이용하여 생존 종양 부위를 예측하고자 하였다. 특히 치료 전 낮은 확산 강조 영상이 치료 후 종양 재발까지 의 기간 감소와 연관이 있다는 연구가 많았다(38-41). 치료 후에 교모세포종 환자에서 확산 강조 
Fig. 5. Voxel-wise clustering method of ADC and $\mathrm{rCBV}$ map analysis to demonstrate spatial heterogeneity in the glioblastoma post-treatment. Two subsequent images obtained after concurrent chemoradiotherapy displays the three distinct regions exhibiting temporal changes, which are created based on the K-means clustering method.

$\mathrm{ADC}=$ apparent diffusion coefficient, $\mathrm{nCBV}=$ normalized cerebral blood volume, $\mathrm{rCBV}=$ relative cerebral blood volume
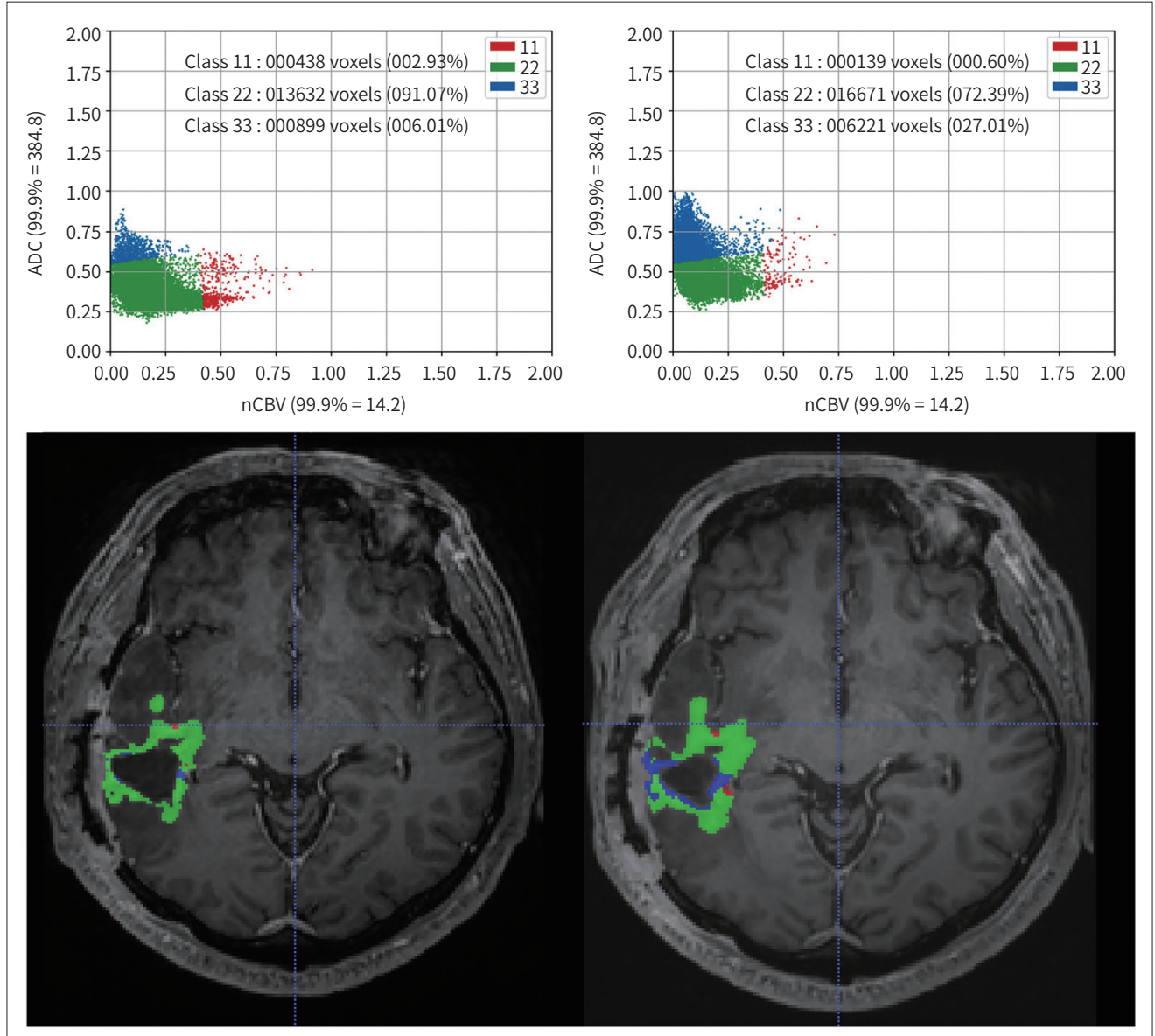

영상 소견의 해석에는 주의를 요하는데, 특히 낮은 $\mathrm{ADC}$ 값을 보이는 부위가 생존 종양 부위만을 의미하는 것이 아니라, 항혈관제에 의해 감소된 혈관투과도, 만성 저산소 공급과 항혈관제에 의한 응고성 괴사로 인해 낮은 $\mathrm{ADC}$ 값을 보일 수 있기 때문이다(41-43). 관류 영상은 항혈관제 치료 전 후 평가에 있어서 이전 연구 결과에 의하면, 치료 전과 후의 rCBV를 측정함으로써 치료 반응을 일 부 예측할 수 있다. 치료 전 rCBV가 높은 군은 항혈관제 치료 후 나쁜 예후를 보였으며(44-46), 치 료 후 rCBV가 많이 감소된 군에서 좋은 예후를 나타냈다(47). 최근 연구에서 치료 후 높은 rCBV는 특히 국소 재발(local recurrence)과 연관성이 높았다(48).

\section{뇌종양에서의 라디오믹스와 딥러닝의 응용 및 미래적 가치}

\section{라디오믹스}

영상은 ‘그림보다 데이터'라는 말은(49) 라디오믹스의 속성을 잘 표현하고 있다. 라디오믹스는 영 
Fig. 6. Common radiomic features of volume and shape describing morphology, a first-order feature describing intensity histogram using first-order statistics, textural features describing a GLCM and GLRLM computing relationship between adjacent voxels, and wavelet transformation describing discrete wavelet transformation of a high-pass and low-pass filter.

$\mathrm{GLCM}$ = gray-level co-occurrence matrix, GLRLM = gray-level run-length matrix

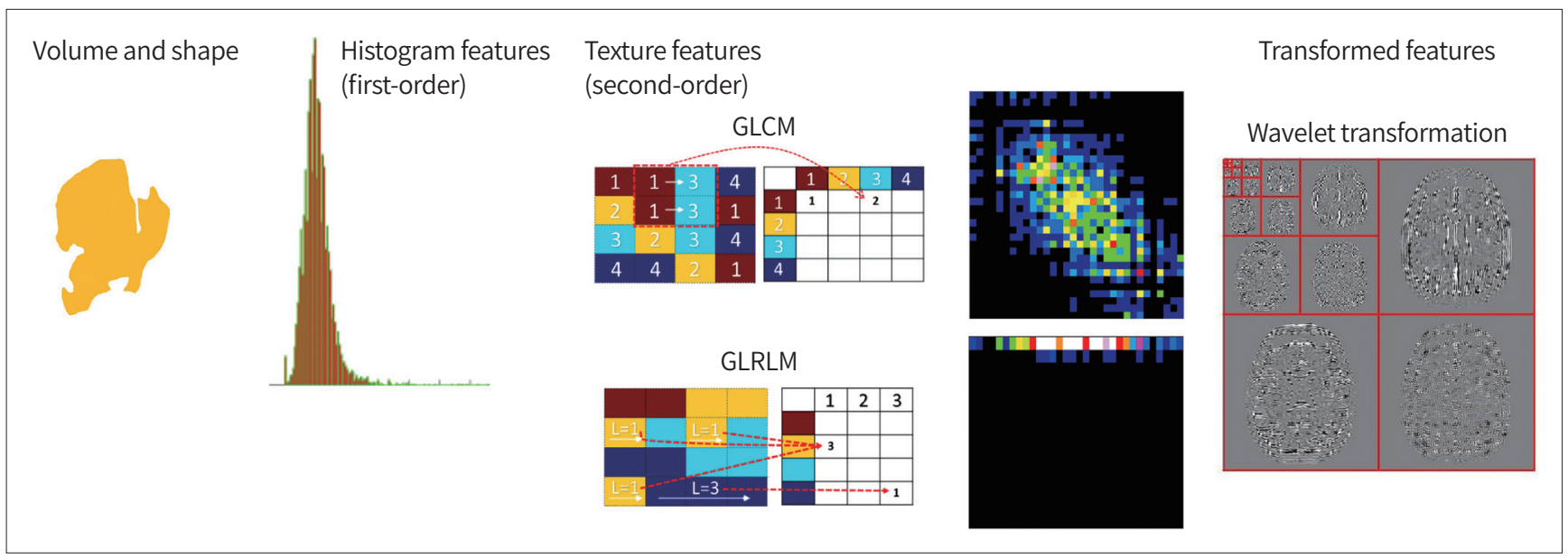

상을 추출 가능한 데이터로 파악하여 정량적이고 다차원의(high-dimensional) 데이터로 만드는 기술로, 영상을 가공하고 분석하여 수백 가지에서 수천 가지에 이르는 영상 지표를 추출하는 방법 이다. 라디오믹스의 특징은 크게 세 가지로 요약된다. 첫째로 영상 데이터를 이용하여 자동화되고 정량적인 분석을 함으로써, 정성적이고 영상을 분석하는 사람에 따라 달라지는 기존의 방법에 비 하여 객관적인 영상 지표를 추출할 수 있다. 두 번째로는 많은 양의 다차원 데이터를 이용하여 종 양 내 복잡성을 이해하고 이질성을 반영하는데 좋은 지표로 사용될 수 있다. 세 번째로는 한 환자 에게서 추출된 많은 영상 지표를 가지고 임상 결과에 대해서 논리적인 데이터 모델을 구축함으로 써 환자 개개인에게 정교한 맞춤의학(precision medicine)을 실현하고자 하는데 목적이 있다.

라디오믹스에서 다루는 영상 지표는 다음과 같다. 1) 영상 신호의 높낮이의 분포를 나타내는 히 스토그램(histogram) 지표, 2) 인접한 복셀 사이의 신호 관계를 나타내는 질감(텍스쳐, texture) 지 표, 3) 영상 신호 변환 후 분석하는 웨이블릿(wavelet), 라플라시안(Laplacian) 변환 지표, 4) 편광 (fractal) 지표 등이다(Fig. 6).

라디오믹스 분석은 많은 정량 지표를 가지고 몇 개의 임상 결과나 유전체 결과에 대해 데이터 모델을 구축하기 때문에, 데이터 과적합(overfitting)이 일어나기 쉬우며 따라서 머신러닝 기법을 이용하여 불필요한 데이터를 제거하고 과적합을 방지하게 된다. 데이터 모델 구축에 있어 주의점 을 다룬 리뷰(50)를 참고하기 바란다.

라디오믹스는 2014년도 Aerts 등(51)의 연구 이후로 많은 연구가 있었으며, 뇌종양 분야에서도 많은 연구가 이루어졌다. 뇌종양에서는 종양과 비종양의 감별, 뇌종양 내에서의 분류, 종양 등급 결정, 치료 반응 예측 연구가 있었다. 특히 이전 정성적인 방법이나 몇 개의 해부학적, 생리학적 영 상 지표로는 진단이나 예측이 어려웠던 주제에 대하여 다루고 있다. 대표적 연구를 예시로 소개하 고자 한다. 


\section{종양의 분류}

기존 영상 분석으로 감별이 어려웠던 뇌종양의 감별 진단에 이용되었다. 뇌교종과 전이암을 분 류하는데 해부학적 영상의 질감(texture) 지표를 이용했을 때 약 $85 \%$ 의 정확도를 보였다(52). 해 부학적 영상뿐 아니라 $\mathrm{ADC}$ 영상도 라디오믹스에 이용되었는데, $\mathrm{ADC}$ 라디오믹스를 이용하였을 때 뇌교종과 악성림프종을 분류하는데 약 $95 \%$ 의 정확도를 보였다(53). 최근 조영증강 $\mathrm{T} 1$ 강조영 상을 이용하여 전이암 기원 세포에 대한 감별진단 연구가 있었으며, 폐암에서의 전이 예측에 area under the curve (이하 $\mathrm{AUC}$ )는 0.64, 악성 흑색종(melanoma)에서의 전이 예측에는 $\mathrm{AUC} 0.82$ 를 보였다(54).

\section{유전체와의 연계}

기존 영상법으로 유전체 변이 예측은 진단이 어려우며, 임상적으로 중요하여 라디오믹스를 이 용한 진단 연구가 많이 이루어져 왔다. 교종에서는 아이소시트레이트 탈수소효소(IDH) (55-58) 예 측 연구를 가장 많이 하였다. 라디오믹스는 앞서 언급했듯이 다차원 데이터를 이용하여 종양 내 복잡성을 이해하고 이질성을 반영할 수 있기 때문에, 라디오믹스를 이용하여 1 2개의 유전체 변 이를 예측하기보다는 종양 내 여러 유전체를 예측하는 것이 더 바람직할 것으로 생각된다. 대표적 연구들로는 2016년도에 Kickingereder 등(59)이 확산 강조 영상, 관류 영상, 자화강조 영상의 히 스토그램 지표 이용하여 교모세포종에서 DNA 메틸화 및 copy number variation을 예측한 연구 가 있고, 이후 $\mathrm{Hu}$ 등(60)이 교모세포종에서 48건의 영상유도 생검 검체와 해부학적 영상을 이용한 라디오믹스를 연관 분석하여 유전체 변이를 진단한 연구가 있다. 2020년도에는 Park 등(61)이 교 모세포종에서 확산 강조 영상 및 관류 영상 라디오믹스를 이용하여 차세대 염기서열 분석(next generation sequencing)을 통해 분석한 유전체 변이를 예측한 연구가 라디오믹스의 다차원 데이 터를 강조한 연구라고 할 수 있다.

\section{생존 및 치료 반응 예측}

라디오믹스를 통한 종양 내 이질성 및 복잡성은 곧 종양 내 서로 다른 세포의 군집을 반영한다. 이는 결국 치료를 한 종양에서 세포 군집마다 다른 치료 반응을 만들며, 치료에 대한 내성을 나타 내기 때문에 중요하다. 종양 치료에 대한 내성은 환자의 예후에 영향을 주므로, 라디오믹스를 통 하여 영상에서 이러한 복잡성을 반영하는 것은 중요하며 생존 및 치료 반응 예측에 이용할 수 있 다. 생존 분석의 경우 기존의 잘 알려진 임상 정보에 더하여 라디오믹스를 이용한 모델링을 통하 여 생존을 분석하는 것이 가장 흔한 형태의 연구이다. 난치성 뇌종양인 교모세포종에서 가장 연구 가 많이 되어 왔으며, 진단 당시 나이, 수술 범위 등 임상 정보에 더해서 연구가 있으며(62) 또는 유 전체 정보에 더해서 라디오믹스를 결합했을 때 생존 예측에 나아진 성능을 보였다(63, 64).

교모세포종의 치료 반응 평가에 있어 RANO criteria에서 한계점으로 언급하고 있는 것은 거짓 진행으로, 기존 해부학적 영상뿐만 아니라 생리적 영상 지표를 이용하여도 예측에 한계점이 있다. 교모세포종 항암 화학 치료 후 12 주 이내에 커지는 조영증강 병변을 라디오믹스로 분석하는 연구 가 이루어졌는데, 특히 관류 영상을 이용한 분석이 유망한 것으로 생각된다. 관류 영상 지표인 
Ktrans나 CBV를 라디오믹스 분석을 통하여 높은 예측력을 보여준 연구가 있으며(65), 단순 파라 미터인 평균 $\mathrm{ADC}$ 나 $\mathrm{CBV}$ 보다 라디오믹스를 이용한 $\mathrm{ADC}, \mathrm{CBV}$ 분석이 더 예측력이 좋다는 연구 가 있다(66). 이 두 연구는 특히 외부 병원 데이터를 확보하여 검증하였기에 더 의미가 있다.

\section{뇌종양에서 딥러닝의 미래적 가치}

딥러닝은 머신 러닝의 한 종류이며, 인공지능에 포함된다. 딥러닝은 인공 신경망을 기반으로 다 층적인 구조를 갖고 있으며 이로 인하여 많은 데이터의 빠른 연산이 가능하도록 한다. 딥러닝은 영상 데이터뿐만 아니라 앞선 단락에서의 라디오믹스와 결합하여 다양한 분석을 할 수 있으며 뇌 종양 영상에서도 다양한 응용이 기대된다.

딥러닝에는 인공 신경망의 독특한 형태인 컨볼루션 신경망(convolutional neural network), 오 토 인코더(autoencoder), 순환신경망(recurrent neural network) 등의 다양한 기술이 있으며, 이 러한 기술적인 측면은 다른 리뷰에서 상세히 다루고 있다(67). 뇌종양에서 딥러닝의 응용은 주로 컨볼루션 신경망을 이용한 질환의 진단적인 분류(classification)이며(68) 기존 다른 영상 바이오 마커에서 다루었던 종양 분류, 유전체 변이 진단, 예후 예측 등이다(69).

딥러닝을 이용한 진단능 연구는 아직 임상 검증이 되지 않아 초기 단계이며(70), 본 종설에서는 다루지 않았다. 딥러닝을 이용한 진단은 많은 데이터를 필요로 하며, 과적합이 문제가 되어 독립 된 검증에 주의를 기울여야 한다. 본 종설에서는 뇌종양에서 분류(classification) 주제 이외에 향 후 가치가 높은 딥러닝의 응용에 대해서 간략히 언급하고자 한다.

\section{뇌종양에서 조영증강 병변의 객관적이며 자동화된 측정}

딥러닝을 이용한 종양 분절화(segmentation)는 비지도학습(unsupervised learning)의 한 종 류로서 많은 연구에서 이루어져 왔다(71-73). 종양 분절화는 뇌종양의 부피를 객관적으로 측정하 여 치료 반응을 평가하는데 직접적인 도움을 줄 수 있다(Fig. 7). 최근 딥러닝을 이용하여 교모세포 종에서 조영증강 부피를 자동으로 측정한 뒤, 기존 단면에서 장축 및 단축의 길이를 측정하는 $\mathrm{RANO}$ 평가와 비교하는 연구가 있었다(74). 임상시험에 등록된 유럽 뇌종양 데이터에서 딥러닝을 이용한 조영증강 부피 측정은 기존 RANO 평가와 비교하였을 때 생존에 대한 예측력이 좋았다.

또한, 여러 영상 바이오마커는 분절화된 종양에서 값을 추출하게 된다. 높은 재현성을 갖는 자 동화된 종양 분절화는 영상 정량 분석의 ‘주형(template)'이 되기 때문에(75-78), 딥러닝을 이용한 종양 분절화는 향후 많은 임상응용이 기대된다.

\section{자동화된 전이 병변 발견에 의한 업무 효율성 증대}

폐선암 환자는 뇌 $\mathrm{MRI}$ 를 촬영하여 뇌 전이병변 여부를 평가함으로써 병기 진단을 하게 된다. 영상의학과 의사에게 업무량이 매우 많으며, 작은 뇌전이 병변을 발견하는 것은 시간이 오래 걸리 며 재현성이 낮은 일 중 하나이다. 딥러닝 기술을 이용하여 작은 조영증강 병변을 찾아내는 알고 리듬을 개발한다면, 이를 영상의학과 의사가 한 번 더 확인함으로써 진단 정확도를 향상시키며 업 
Fig. 7. Examples of deep learning-based automatic segmentation.

Most of the contrast-enhancing tumor portions were accurately segmented by deep learning (red) compared with the reference human segmentation (green).

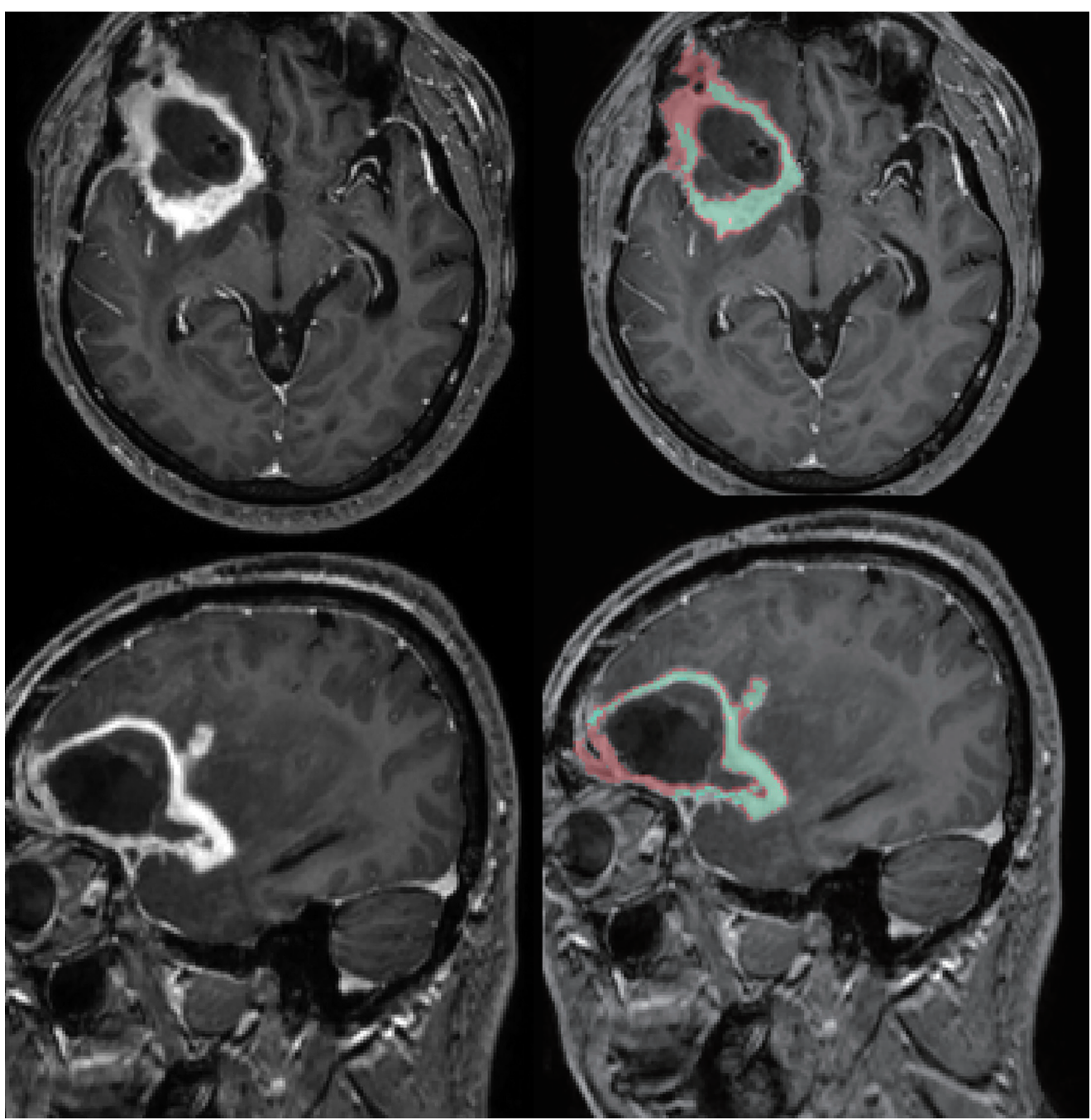

무 효율성을 높일 수 있을 것으로 생각된다. 자동화된 뇌 전이 병변의 발견에 대한 기술적인 개발 이 이루어져 왔으며(79-81), 이러한 알고리듬을 영상의학과 의사에게 보급하였을 때 $2 \mathrm{~mm}$ 크기 이상의 뇌전이 병변을 찾는 민감도가 $89.8 \%$ 에서 $100 \%$ 로 증가했다고 밝히고 있다(80). 향후 이를 실제 업무에 적용시키고 검증하는 노력이 필요할 것으로 생각된다.

뇌종양 병변의 가상 합성(Synthetic Data Generation)을 이용한 데이터 보강(Augmentation) 및 인공지능 학습의 강화

최근 가상 영상의 생성 기술인 생산적 적대적 네트워크(generative adversarial network; GAN)가 주목받고 있다. 이는 딥러닝 기술을 이용하여 가상의 영상을 생성한 뒤, 실제 영상과 적대 적으로 겨루어 실제와 구분이 어려울 때까지 영상을 생성하도록 학습하는 방법으로, 영상에서 노 이즈 제거나 높은 해상도 영상을 재구성하는 데에 이용되고 있다(82). 악성 뇌종양은 희귀 난치성 
질환으로 영상을 이용한 빅데이터 구축에 어려움이 있으며, 병원 간 국가 간 연계 부족에 따른 양 질의 데이터(use case) 부족에 늘 직면하여 있다. 딥러닝 기술을 이용하여 뇌종양 영상 데이터를 생성한다면, 앞서 언급하였던 딥러닝을 이용한 분류(classification)의 성능이 큰 폭으로 향상될 것으로 생각되며, 귀추가 주목된다.

\section{결론}

뇌 교종 및 전이성 뇌암에 대한 영상 촬영 가이드라인에 맞추어 해부학적인 뇌종양 영상기법을 개선하는 노력이 필요하다. 확산 강조 영상과 동적 자화 강조 영상 또한 다기관 연구 및 임상시험 에 적용하고 있으며, 영상의학과 의사가 뇌종양 병태생리와의 연관성에 대해 이해하고 응용하는 것이 중요하다. 종양의 유전체 변이와 이질성 평가가 중요해지면서 라디오믹스와 딥러닝을 이용 한 영상분석기법의 임상 응용이 기대되고 있으며, 향후에는 딥러닝을 이용하여 임상 업무 효율성 을 증대하고 데이터를 이용하여 개선된 학습을 할 수 있으리라 기대된다.

\section{Author Contributions}

Conceptualization, all authors; data curation, P.J.E.; methodology, K.H.S.; visualization, P.J.E.; writing-original draft, P.J.E.; and writing-review \& editing, K.H.S.

\section{Conflicts of Interest}

The authors have no potential conflicts of interest to disclose.

\section{Acknowledgments}

This research was supported by a grant of the Basic Science Research Program through the National Research Foundation of Korea (2020R1A2B5B01001707).

\section{REFERENCES}

1. Upadhyay N, Waldman AD. Conventional MRI evaluation of gliomas. Br J Radiol 2011;84 Spec No 2:S107S111

2. Pope WB, Brandal G. Conventional and advanced magnetic resonance imaging in patients with high-grade glioma. Q J Nucl Med Mol Imaging 2018;62:239-253

3. Jain R, Johnson DR, Patel SH, Castillo M, Smits M, Bent MJVD, et al. 'Real world' use of a highly reliable imaging sign: 'T2-FLAIR mismatch' for identification of IDH mutant astrocytomas. Neuro Oncol. 2020 [In press] doi: https://doi.org/10.1093/neuonc/noaa041

4. Broen MPG, Smits M, Wijnenga MMJ, Dubbink HJ, Anten MHME, Schijns OEMG, et al. The T2-FLAIR mismatch sign as an imaging marker for non-enhancing IDH-mutant, 1p/19q-intact lower-grade glioma: a validation study. Neuro Oncol 2018;20:1393-1399

5. Patel SH, Poisson LM, Brat DJ, Zhou Y, Cooper L, Snuderl M, et al. T2-FLAIR mismatch, an imaging biomarker for IDH and 1p/19q status in lower-grade gliomas: a TCGA/TCIA project. Clin Cancer Res 2017;23:6078-6085

6. Wen PY, Macdonald DR, Reardon DA, Cloughesy TF, Sorensen AG, Galanis E, et al. Updated response assessment criteria for high-grade gliomas: response assessment in neuro-oncology working group. J Clin Oncol 2010;28:1963-1972

7. Ellingson BM, Bendszus M, Boxerman J, Barboriak D, Erickson BJ, Smits M, et al. Consensus recommendations for a standardized Brain Tumor Imaging Protocol in clinical trials. Neuro Oncol 2015;17:1188-1198

8. Ostrom QT, Cioffi G, Gittleman H, Patil N, Waite K, Kruchko C, et al. CBTRUS statistical report: primary brain and other central nervous system tumors diagnosed in the United States in 2012-2016. Neuro Oncol 2019;21:v1-v100 
9. Kaufmann TJ, Smits M, Boxerman J, Huang R, Barboriak DP, Weller M, et al. Consensus recommendations for a standardized brain tumor imaging protocol for clinical trials in brain metastases (BTIP-BM). Neuro Oncol 2020 [In press] doi: https://doi.org/10.1093/neuonc/noaa030

10. Davis FG, Dolecek TA, McCarthy BJ, Villano JL. Toward determining the lifetime occurrence of metastatic brain tumors estimated from 2007 United States cancer incidence data. Neuro Oncol 2012;14:1171-1177

11. Lin NU, Lee EQ, Aoyama H, Barani IJ, Barboriak DP, Baumert BG, et al. Response assessment criteria for brain metastases: proposal from the RANO group. Lancet Oncol 2015;16:e270-e278

12. Ellingson BM, Malkin MG, Rand SD, Connelly JM, Quinsey C, LaViolette PS, et al. Validation of functional diffusion maps (fDMs) as a biomarker for human glioma cellularity. J Magn Reson Imaging 2010;31:538-548

13. Sugahara T, Korogi Y, Kochi M, Ikushima I, Shigematu Y, Hirai T, et al. Usefulness of diffusion-weighted MRI with echo-planar technique in the evaluation of cellularity in gliomas. J Magn Reson Imaging 1999;9:53-60

14. Chen L, Liu M, Bao J, Xia Y, Zhang J, Zhang L, et al. The correlation between apparent diffusion coefficient and tumor cellularity in patients: a meta-analysis. PLoS One 2013;8:e79008

15. Rose S, Fay M, Thomas P, Bourgeat P, Dowson N, Salvado O, et al. Correlation of MRI-derived apparent diffusion coefficients in newly diagnosed gliomas with [18F]-fluoro-L-dopa PET: what are we really measuring with minimum ADC? AJNR Am J Neuroradiol 2013;34:758-764

16. Choi H, Paeng JC, Cheon GJ, Park CK, Choi SH, Min HS, et al. Correlation of 11C-methionine PET and diffusion-weighted MRI: is there a complementary diagnostic role for gliomas? Nucl Med Commun 2014;35:720726

17. Kim M, Kim HS. Emerging techniques in brain tumor imaging: what radiologists need to know. Korean J Radiol 2016;17:598-619

18. Cha S, Knopp EA, Johnson G, Wetzel SG, Litt AW, Zagzag D. Intracranial mass lesions: dynamic contrast-enhanced susceptibility-weighted echo-planar perfusion MR imaging. Radiology 2002;223:11-29

19. Puig J, Biarnés C, Daunis-I-Estadella P, Blasco G, Gimeno A, Essig M, et al. Macrovascular networks on contrast-enhanced magnetic resonance imaging improves survival prediction in newly diagnosed glioblastoma. Cancers (Basel) 2019;11:E84

20. Hakyemez B, Erdogan C, Bolca N, Yildirim N, Gokalp G, Parlak M. Evaluation of different cerebral mass lesions by perfusion-weighted MR imaging. J Magn Reson Imaging 2006;24:817-824

21. Floriano VH, Torres US, Spotti AR, Ferraz-Filho JR, Tognola WA. The role of dynamic susceptibility contrastenhanced perfusion MR imaging in differentiating between infectious and neoplastic focal brain lesions: results from a cohort of 100 consecutive patients. PLoS One 2013;8:e81509

22. Blasel S, Pfeilschifter W, Jansen V, Mueller K, Zanella F, Hattingen E. Metabolism and regional cerebral blood volume in autoimmune inflammatory demyelinating lesions mimicking malignant gliomas. J Neurol 2011;258:113-122

23. Bhagavathi S, Wilson JD. Primary central nervous system lymphoma. Arch Pathol Lab Med 2008;132:18301834

24. Xu W, Wang Q, Shao A, Xu B, Zhang J. The performance of MR perfusion-weighted imaging for the differentiation of high-grade glioma from primary central nervous system lymphoma: a systematic review and metaanalysis. PLoS One 2017;12:e0173430

25. Kickingereder P, Wiestler B, Sahm F, Heiland S, Roethke M, Schlemmer HP, et al. Primary central nervous system lymphoma and atypical glioblastoma: multiparametric differentiation by using diffusion-, perfusion-, and susceptibility-weighted MR imaging. Radiology 2014;272:843-850

26. Kruser TJ, Mehta MP, Robins HI. Pseudoprogression after glioma therapy: a comprehensive review. Expert Rev Neurother 2013;13:389-403

27. Brandes AA, Franceschi E, Tosoni A, Blatt V, Pession A, Tallini G, et al. MGMT promoter methylation status can predict the incidence and outcome of pseudoprogression after concomitant radiochemotherapy in newly diagnosed glioblastoma patients. J Clin Oncol 2008;26:2192-2197

28. Filli L, Wurnig M, Nanz D, Luechinger R, Kenkel D, Boss A. Whole-body diffusion kurtosis imaging: initial experience on non-Gaussian diffusion in various organs. Invest Radiol 2014;49:773-778

29. Chu HH, Choi SH, Ryoo I, Kim SC, Yeom JA, Shin H, et al. Differentiation of true progression from pseudoprogression in glioblastoma treated with radiation therapy and concomitant temozolomide: comparison study of standard and high-b-value diffusion-weighted imaging. Radiology 2013;269:831-840

30. Mangla R, Singh G, Ziegelitz D, Milano MT, Korones DN, Zhong J, et al. Changes in relative cerebral blood 
volume 1 month after radiation-temozolomide therapy can help predict overall survival in patients with glioblastoma. Radiology 2010;256:575-584

31. Blasel S, Zagorcic A, Jurcoane A, Bähr O, Wagner M, Harter PN, et al. Perfusion MRI in the evaluation of suspected glioblastoma recurrence. J Neuroimaging 2016;26:116-123

32. Patel P, Baradaran H, Delgado D, Askin G, Christos P, John Tsiouris A, et al. MR perfusion-weighted imaging in the evaluation of high-grade gliomas after treatment: a systematic review and meta-analysis. Neuro Oncol 2017;19:118-127

33. Hamstra DA, Chenevert TL, Moffat BA, Johnson TD, Meyer CR, Mukherji SK, et al. Evaluation of the functional diffusion map as an early biomarker of time-to-progression and overall survival in high-grade glioma. Proc Natl Acad Sci U SA 2005;102:16759-16764

34. Tsien C, Galbán CJ, Chenevert TL, Johnson TD, Hamstra DA, Sundgren PC, et al. Parametric response map as an imaging biomarker to distinguish progression from pseudoprogression in high-grade glioma. J Clin Oncol 2010;28:2293-2299

35. Chinot OL, Wick W, Mason W, Henriksson R, Saran F, Nishikawa R, et al. Bevacizumab plus radiotherapy-temozolomide for newly diagnosed glioblastoma. N Engl J Med 2014;370:709-722

36. Gilbert MR, Dignam JJ, Armstrong TS, Wefel JS, Blumenthal DT, Vogelbaum MA, et al. A randomized trial of bevacizumab for newly diagnosed glioblastoma. N Engl J Med 2014;370:699-708

37. Wick W, Brandes A, Gorlia T, Bendszus M, Sahm F, Taal W, et al. LB-05 phase III trial exploring the combination of bevacizumab and lomustine in patients with first recurrence of a glioblastoma: the EORTC 26101 trial. Neuro-Oncology 2015;17:v1

38. Pope WB, Kim HJ, Huo J, Alger J, Brown MS, Gjertson D, et al. Recurrent glioblastoma multiforme: ADC histogram analysis predicts response to bevacizumab treatment. Radiology 2009;252:182-189

39. Ellingson BM, Gerstner ER, Smits M, Huang RY, Colen R, Abrey LE, et al. Diffusion MRI phenotypes predict overall survival benefit from anti-VEGF monotherapy in recurrent glioblastoma: converging evidence from phase II trials. Clin Cancer Res 2017;23:5745-5756

40. Ellingson BM, Gerstner ER, Smits M, Huang RY, Colen R, Abrey LE, et al. Diffusion MRI phenotypes predict overall survival benefit from anti-VEGF monotherapy in recurrent glioblastoma: converging evidence from phase II trials. Clin Cancer Res 2017;23:5745-5756

41. Rahman R, Hamdan A, Zweifler R, Jiang H, Norden AD, Reardon DA, et al. Histogram analysis of apparent diffusion coefficient within enhancing and nonenhancing tumor volumes in recurrent glioblastoma patients treated with bevacizumab. J Neurooncol 2014;119:149-158

42. Nguyen HS, Milbach N, Hurrell SL, Cochran E, Connelly J, Bovi JA, et al. Progressing bevacizumab-induced diffusion restriction is associated with coagulative necrosis surrounded by viable tumor and decreased overall survival in patients with recurrent glioblastoma. AJNR Am J Neuroradiol 2016;37:2201-2208

43. Thomas A, Rosenblum M, Karimi S, DeAngelis LM, Omuro A, Kaley TJ. Radiographic patterns of recurrence and pathologic correlation in malignant gliomas treated with bevacizumab. CNS Oncol 2018;7:7-13

44. Schmainda KM, Prah M, Connelly J, Rand SD, Hoffman RG, Mueller W, et al. Dynamic-susceptibility contrast agent MRI measures of relative cerebral blood volume predict response to bevacizumab in recurrent highgrade glioma. Neuro Oncol 2014;16:880-888

45. Kickingereder P, Wiestler B, Burth S, Wick A, Nowosielski M, Heiland S, et al. Relative cerebral blood volume is a potential predictive imaging biomarker of bevacizumab efficacy in recurrent glioblastoma. Neuro Oncol 2015;17:1139-1147

46. Verhoeff JJ, Lavini C, Van Linde ME, Stalpers LJ, Majoie CB, Reijneveld JC, et al. Bevacizumab and dose-intense temozolomide in recurrent high-grade glioma. Ann Oncol 2010;21:1723-1727

47. Schmainda KM, Zhang Z, Prah M, Snyder BS, Gilbert MR, Sorensen AG, et al. Dynamic susceptibility contrast MRI measures of relative cerebral blood volume as a prognostic marker for overall survival in recurrent glioblastoma: results from the ACRIN 6677/RTOG 0625 multicenter trial. Neuro Oncol 2015;17:1148-1156

48. Park JE, Kim HS, Park SY, Jung SC, Kim JH, Heo HY. Identification of early response to anti-angiogenic therapy in recurrent glioblastoma: amide proton transfer-weighted and perfusion-weighted MRI compared with diffusion-weighted MRI. Radiology 2020;295:397-406

49. Gillies RJ, Kinahan PE, Hricak H. Radiomics: images are more than pictures, they are data. Radiology 2016;278:563-577

50. Park JE, Park SY, Kim HJ, Kim HS. Reproducibility and generalizability in radiomics modeling: possible strat- 
egies in radiologic and statistical perspectives. Korean J Radiol 2019;20:1124-1137

51. Aerts HJ, Velazquez ER, Leijenaar RT, Parmar C, Grossmann P, Carvalho S, et al. Decoding tumour phenotype by noninvasive imaging using a quantitative radiomics approach. Nat Commun 2014;5:4006

52. Zacharaki EI, Wang S, Chawla S, Soo Yoo D, Wolf R, Melhem ER, et al. Classification of brain tumor type and grade using MRI texture and shape in a machine learning scheme. Magn Reson Med 2009;62:1609-1618

53. Kang D, Park JE, Kim YH, Kim JH, Oh JY, Kim J, et al. Diffusion radiomics as a diagnostic model for atypical manifestation of primary central nervous system lymphoma: development and multicenter external validation. Neuro Oncol 2018;20:1251-1261

54. Kniep HC, Madesta F, Schneider T, Hanning U, Schönfeld MH, Schön G, et al. Radiomics of brain MRI: utility in prediction of metastatic tumor type. Radiology 2019;290:479-487

55. Zhang X, Tian Q, Wang L, Liu Y, Li B, Liang Z, et al. Radiomics strategy for molecular subtype stratification of lower-grade glioma: detecting IDH and TP53 mutations based on multimodal MRI. J Magn Reson Imaging 2018;48:916-926

56. Yu J, Shi Z, Lian Y, Li Z, Liu T, Gao Y, et al. Noninvasive IDH1 mutation estimation based on a quantitative radiomics approach for grade II glioma. EurRadiol 2017;27:3509-3522

57. Kim M, Jung SY, Park JE, Jo Y, Park SY, Nam SJ, et al. Diffusion- and perfusion-weighted MRI radiomics model may predict isocitrate dehydrogenase (IDH) mutation and tumor aggressiveness in diffuse lower grade glioma. Eur Radiol 2020;30:2142-2151

58. Arita H, Kinoshita M, Kawaguchi A, Takahashi M, Narita Y, Terakawa Y, et al. Lesion location implemented magnetic resonance imaging radiomics for predicting IDH and TERT promoter mutations in grade II/III gliomas. Sci Rep 2018;8:11773

59. Kickingereder P, Bonekamp D, Nowosielski M, Kratz A, Sill M, Burth S, et al. Radiogenomics of glioblastoma: machine learning-based classification of molecular characteristics by using multiparametric and multiregional MR imaging features. Radiology 2016;281:907-918

60. Hu LS, Ning S, Eschbacher JM, Baxter LC, Gaw N, Ranjbar S, et al. Radiogenomics to characterize regional genetic heterogeneity in glioblastoma. Neuro Oncol 2017;19:128-137

61. Park JE, Kim HS, Park SY, Nam SJ, Chun SM, Jo Y, et al. Prediction of core signaling pathway by using diffusion- and perfusion-based MRI radiomics and next-generation sequencing in isocitrate dehydrogenase wild-type glioblastoma. Radiology 2020;294:388-397

62. Kickingereder P, Burth S, Wick A, Götz M, Eidel O, Schlemmer HP, et al. Radiomic profiling of glioblastoma: identifying an imaging predictor of patient survival with improved performance over established clinical and radiologic risk models. Radiology 2016;280:880-889

63. Bae S, Choi YS, Ahn SS, Chang JH, Kang SG, Kim EH, et al. Radiomic MRI phenotyping of glioblastoma: improving survival prediction. Radiology 2018;289:797-806

64. Kickingereder P, Neuberger U, Bonekamp D, Piechotta PL, Götz M, Wick A, et al. Radiomic subtyping improves disease stratification beyond key molecular, clinical, and standard imaging characteristics in patients with glioblastoma. Neuro Oncol 2018;20:848-857

65. Elshafeey N, Kotrotsou A, Hassan A, Elshafei N, Hassan I, Ahmed S, et al. Multicenter study demonstrates radiomic features derived from magnetic resonance perfusion images identify pseudoprogression in glioblastoma. Nat Commun 2019;10:3170

66. Kim JY, Park JE, Jo Y, Shim WH, Nam SJ, Kim JH, et al. Incorporating diffusion- and perfusion-weighted MRI into a radiomics model improves diagnostic performance for pseudoprogression in glioblastoma patients. Neuro Oncol 2019;21:404-414

67. Lee JG, Jun S, Cho YW, Lee H, Kim GB, Seo JB, et al. Deep learning in medical imaging: general overview. Korean J Radiol 2017;18:570-584

68. Park SH. Artificial intelligence in medicine: beginner's guide. J Korean Soc Radiol 2018;78:301-308

69. Rudie JD, Rauschecker AM, Bryan RN, Davatzikos C, Mohan S. Emerging applications of artificial intelligence in neuro-oncology. Radiology 2019;290:607-618

70. Park SH, Han K. Methodologic guide for evaluating clinical performance and effect of artificial intelligence technology for medical diagnosis and prediction. Radiology 2018;286:800-809

71. Weston AD, Korfiatis P, Kline TL, Philbrick KA, Kostandy P, Sakinis T, et al. Automated abdominal segmentation of CT scans for body composition analysis using deep learning. Radiology 2019;290:669-679

72. Lin L, Dou Q, Jin YM, Zhou GQ, Tang YQ, Chen WL, et al. Deep learning for automated contouring of primary 
tumor volumes by MRI for nasopharyngeal carcinoma. Radiology 2019;291:677-686

73. Norman B, Pedoia V, Majumdar S. Use of 2D U-Net convolutional neural networks for automated cartilage and meniscus segmentation of knee MR imaging data to determine relaxometry and morphometry. Radiology 2018;288:177-185

74. Kickingereder P, Isensee F, Tursunova I, Petersen J, Neuberger U, Bonekamp D, et al. Automated quantitative tumour response assessment of MRI in neuro-oncology with artificial neural networks: a multicentre, retrospective study. Lancet Oncol 2019;20:728-740

75. Kumar V, Gu Y, Basu S, Berglund A, Eschrich SA, Schabath MB, et al. Radiomics: the process and the challenges. Magn Reson Imaging 2012;30:1234-1248

76. Lambin P, Leijenaar RTH, Deist TM, Peerlings J, De Jong EEC, Van Timmeren J, et al. Radiomics: the bridge between medical imaging and personalized medicine. Nat Rev Clin Oncol 2017;14:749-762

77. Lambin P, Rios-Velazquez E, Leijenaar R, Carvalho S, Van Stiphout RG, Granton P, et al. Radiomics: extracting more information from medical images using advanced feature analysis. Eur J Cancer 2012;48:441-446

78. Park JE, Kim HS. Radiomics as a quantitative imaging biomarker: practical considerations and the current standpoint in neuro-oncologic studies. Nucl Med Mol Imaging 2018;52:99-108

79. Ambrosini RD, Wang P, O'Dell WG. Computer-aided detection of metastatic brain tumors using automated three-dimensional template matching. J Magn Reson Imaging 2010;31:85-93

80. Jun YH, Eo T, Kim T, Shin H, Hwang D, Bae SH, et al. Deep-learned 3D black-blood imaging using automatic labelling technique and 3D convolutional neural networks for detecting metastatic brain tumors. Sci Rep 2018;8:9450

81. Pérez-Ramírez Ú, Arana E, Moratal D. Brain metastases detection on MR by means of three-dimensional tumor-appearance template matching. J Magn Reson Imaging 2016;44:642-652

82. Iqbal T, Ali H. Generative adversarial network for medical images (MI-GAN). J Med Syst 2018;42:231

\section{뇌종양 영상의 현재와 미래}

\section{박지은·김호성*}

뇌종양의 진단 및 치료 반응 평가의 기본이 되는 영상기법은 해부학적 영상이다. 현재 임상 에서 사용 가능한 영상기법들 중 확산 강조 영상 및 관류 영상이 추가적인 정보를 제공하고 있다. 최근에는 종양의 유전체 변이와 이질성 평가가 중요해지면서 라디오믹스와 딥러닝을 이용한 영상분석기법의 임상 응용이 기대되고 있다. 본 종설에서는 뇌종양 영상 임상 적용에 서 여전히 중요한 해부학적 영상을 중심으로 한 자기공명영상 촬영 권고안, 최신 영상기법 중 확산 강조 영상 및 관류 영상의 기본 원리, 병태생리학적 배경 및 임상응용, 마지막으로 최 근 컴퓨터 기술의 발전으로 많이 연구되고 있는 라디오믹스와 딥러닝의 뇌종양에서의 향후 활용가치에 대해 기술하고자 한다. 